\title{
MITIGATION OF HEAVY METALS FROM THE SOIL THROUGH IN-VITRO AND IN-VIVO PRODUCED PLANTS OF IMPATIENTS BALSAMINA L.
}

\author{
Dhruv Pandya*, Archana Mankad and Himanshu Pandya \\ Department of Botany, Bio-informatics, Climate Change Impacts Management, \\ University School of Science, Gujarat University, Ahmedabad, Gujarat, India. \\ *Email id: dhruvpandya1309@gmail.com
}

\begin{abstract}
:
In this research Heavy Metal extraction capacity or phytoremediation capacity of Impatiens balsamina L. was assessed. Here, two different approaches In-vitro and In-vivo were used for the production of plantlets. In-vitro approach involved tissue culture approach and In-vivo direct through media (soil, cocopeat, mosses). Seeds were used for the production of plantlets. After 30 days of seedlings development all the plantlets which are produced through In-vitro and In-vivo approaches and plants were transplanted in the pots and treated with two metals Lead and Cadmium in the form of $\mathrm{Pb}\left(\mathrm{NO}_{3}\right)_{2}$ and $\mathrm{Cd}\left(\mathrm{NO}_{3}\right)_{2}$. Different concentrations were selected for Lead 200mg, 400mg, 600mg, 800mg/ Kg and for Cadmium $5 \mathrm{mg}, 10 \mathrm{mg}, 15 \mathrm{mg}$, and $20 \mathrm{mg} / \mathrm{Kg}$. Each pot was filled with $5 \mathrm{Kg}$ of soil. The metals were given directly through root zone of plants in solution form. After incubation time of 75 days mature and treated plants were collected and each and every part of every concentration treated plants were collected and AAS (Atomic Absorption Spectroscopy) was assessed. As compare to In-vivo produced plants In-vitro produced plants has more capacity to accumulate Lead and Cadmium.
\end{abstract}

Keywords: In-vitro approach, In-vivo approach, Lead, Cadmium, Impatiens balsamina L., Phytoremediatiion.

\section{INTRODUCTION:}

Impatiens balsamina L. belongs to Balsaminaceae family. It is also known as Garden Balsam or Rose Balsam. It is also cultivated in China and Myanmar as an ornamental herb. This is annual ornamental herb and cultivated as seasonal ornamental in India. The plant is generally growing up to $20-75 \mathrm{~cm}$ length with succulent type of branched stem. The leaves are spirally arranged $2.5-9.0 \mathrm{~cm}$ long and $1-2.5 \mathrm{~cm}$ broad and it has toothed margin. The flowers are pink, red, lilac or white and $2.5-5.0 \mathrm{~cm}$ diameter. Generally, it is bees or insect pollinated plant. It has short lifecycle, large number of flowers and various colors of flowers. The plant is not directly used as fodder plant by animal or directly used by humans. So many researchers worked on this plant and it also has different pharmacological activities like Anti-cancer, Anti-ulcer, Antioxidant, Anti-malarial, Antibacterial, Anti-fungal etc. it also has the weedicide potential. Even one researcher also assessed the naphthalene tolerance and remediate capacity of Impatiens balsamina L.

\section{MATERIALS AND METHODOLOGY:}

The seeds were selected for the propagation of plants for both the In-vitro and In-vivo approaches. The experimental work was completed at (Plant Biotechnology Laboratory and Botanical Garden) Botany Department, Gujarat University. 


\section{In-vitro production of plantlets:}

\section{Sources of Explant:}

Seeds were purchased of Fine Grow Company from Alpesh Nursery, Gandhinagar. So, seeds were used as an explant for the production of plantlets. All the seeds were sterilized with the help of $0.1 \% \mathrm{HgCl}_{2}$ solution and $70 \%$ methanol and rewashed with Grade-1 Distil water.

\section{Aseptic Conditions for Production:}

Culture room and the laboratory or transfer room were sterilized through Fumigation technique (Potassium iodide and Formaldehyde were used for it with 2:4 ratio). All the glassware and miscellaneous agents were washed with soap solution and rapped with papers and then sterilized through Autoclave $\left(121^{\circ} \mathrm{C}\right.$ for $\left.20 \mathrm{~min}\right)$. Laminar Air flow hood, weighing scale and all the other small equipment like micropipette were sterilized with $0.1 \%$ mercuric chloride solution and $70 \%$ methanol.

\section{Preparation of M. S. Media for the production of plantlets:}

Here for the practical work most widely used media Murashige and Skoog's media (1962) was used. For the preparation first all the Major, Minor, Iron and Vitamin stalk solutions were prepared as per the Table-1. PGRs were not used because in seeds generally we use to avoid PGRs in In-vitro condition and production of plantlets. Here all the chemicals used for the preparation of stalk solution were Hi Media and SRL company.

Different stalk solutions were prepared in the amount of $500 \mathrm{ml}$ (Major, Minor and Iorn) and $100 \mathrm{ml}$ (Vitamin) and then for the preparation of 1 litter M. S. Media 50ml from Major, 50ml from Minor, $50 \mathrm{ml}$ from Iron and $10 \mathrm{ml}$ from Vitamin stalk were taken and sequentially dissolved and other chemicals which were separately weighed like Myo Inositol, Agar-Agar, Glycine and Sucrose were added for the preparation of media. (Here Grade-1 Purified water was used for the preparation of media with the help of Genie Direct Pure (Rephile) Instrument was used for the preparation of Purified water). After the preparation of media, it was sterilized with the help of autoclave at $121^{\circ} \mathrm{C}$ temperature for $20 \mathrm{~min}$. under the Laminar Air Flow Hood in all the sterilized culture flasks and Glass jars media was poured about $50 \mathrm{ml}$ in each vessel. And all the vessels with media were transferred in Culture room where $25 \pm 1^{\circ} \mathrm{C}$ temperature and sterilized conditions were maintained. After 24 hrs media was ready for the Inoculation process.

\section{Inoculation of Explant:}

All the sterilized seeds were inoculated separately in the jars or culture flasks under the sterilized conditions of Laminar Air flow hood. Different small equipments were used like forceps and scalpels for the inoculation process. After the inoculation of the seeds in the media all the jars and flasks were again transferred carefully at Culture room where $25 \pm 1^{\circ} \mathrm{C}$ temperature and $16 \mathrm{hrs}$ light and $8 \mathrm{hrs}$ darkness was maintained (In seed culture total darkness provided to all the cultures for first 3 days). Incubation time was of 30 days.

\section{In-vivo production of Plantlets:}

By same way sterilized seeds were directly sawed in the media (soil, cocopeat and mosses) in separate pots and regular irrigation process was maintained and up to 15 days the plantlets were produced. The production was carried out at Botanical Garden, Gujarat University.

Now same conditions were provided to all the Invitro and In-vivo produced plantlets. 15 days all 
the plantlets were transferred for the hardening process in the net house of Botanical Garden, Gujarat University where 60\% moisture was maintained. Here same media soil, cocopeat were applied for all the In-vitro and In-vivo produced platelets. After 15 days in the Net house all the mature plants with 8-12 leaves they were transplanted in different pots separately with $5 \mathrm{~kg}$ of soil in each pot. In-vitro and In-vivo produced plants were segregated and potted individually in triplicate sets.

\section{Treatment of Heavy Metal to the plants:}

Lead and Cadmium metals were used for the treatment in the form of Lead nitrate and Cadmium nitrate. For the treatment lead the concentrations were selected $200 \mathrm{mg} / \mathrm{kg}$, $400 \mathrm{mg} / \mathrm{kg}, 600 \mathrm{mg} / \mathrm{kg}, 800 \mathrm{mg} / \mathrm{kg}$ of soil. And for cadmium the concentrations were selected $5 \mathrm{mg} / \mathrm{kg}, 10 \mathrm{mg} / \mathrm{kg}, 15 \mathrm{mg} / \mathrm{kg}, 20 \mathrm{mg} / \mathrm{kg}$ of soil. One set was kept as control both the series and both the approaches. Lead nitrate and Cadmium nitrate solution series were prepared and the treatment was provided to individual directly through rootzone via digging the soil near by the roots.

\section{Incubation time of the plants:}

After the treatment to all the In-vitro and In-vivo produced plantlets all the plants were placed at Botanical Garden for 75 days incubation period. Regular irrigation was done to all the plantlets.

\section{Collection, Drying of the plant parts:}

After the incubation time of 75 days all the plants were collected individually and the parts roots, stem and leaves were segregated and dried in the oven at $80^{\circ} \mathrm{C}$ for 45 minutes. Dried each plant material crushed and weighed $1 \mathrm{gm}$.

\section{Quantitative Estimation of Lead and Cadmium in Plant part:}

All the collected and segregated plant parts of each concentration crushed segregate. 1 gm dry powder of each sample was weighed and taken in to conical flask and $10 \mathrm{ml}$ of concentrated $\mathrm{HNO}_{3}$ was added. The mixture was boiled at constant temperature for $10 \mathrm{~min}$. After cooling $5 \mathrm{ml}$ of $70 \%$ $\mathrm{HClO}_{4}$ was added and the mixture was further boiled until the realise the dense white fumes. After cooling, 20ml distilled water was added and heated until a clear solution was obtained. The mixture was filtered after cooling with the help of Whatman filter paper no. 44 and transferred quantitatively to a $50 \mathrm{ml}$ volumetric flask by adding de-ionized and double distilled water. Samples were analysed through AAS (Atomic Absorption Spectroscopy) for quantification of $\mathrm{Cd}$ and $\mathrm{Pb}$. Results were expressed as $\mathrm{mg} / \mathrm{kg}$ metal content in dry powdered material of respective plant part. The results were collected as Mean \pm S.D. (Standard Deviation).

\section{RESULTS AND DISCUSSION:}

As the results data showed that every plant has some amount of heavy metal with different concentration and as the concentration of the metal increases the amount of phytoextraction rate also increases of both the metals. Roots has maximum accumulation of lead and cadmium metals as compared to stem and leaves. Sekar Kumaran et al in 2013 assesed the lead accumulation capacity of balsam with $100 \mathrm{mg}$ highest concentration treatment. Here in this research $800 \mathrm{mg} / \mathrm{kg}$ metal was provided to the plants so, it's very higher concentration than 100mg. William and Daniel in 2006 described the remediation capacity of one variety of balsam (Populus balsamifera L.) and here in this research Impatiens balsamina L. was analysed with two approaches of plant production. Satashiya et al in 
2017 conducted the experiments in which $9 \mathrm{mg} / \mathrm{kg}$ $\mathrm{Cd}$ and $450 \mathrm{mg} / \mathrm{kg} \mathrm{Pb}$ was provided to the Impatiens balsamina L. plants and in this research $20 \mathrm{mg} / \mathrm{kg} \mathrm{Cd}$ and $800 \mathrm{mg} / \mathrm{kg}$ highest concentration were selected for the treatment. Mohd Zaini Nawahwi et al in 2014 described with experiments Nephthalene accumulation capacity of Impatiens balsamina L. Hiromi et al in 2016 explained the total petroleum hydrocarbon accumulation capacity of Impatiens balsamina L. In future the proteins or the phytochemicals can be identified which are responsible for the extraction of metal and its binding capacity with the help of In-silico analysis.

On the basis of In-vitro and In-vivo plantlet's extraction or uptake capacity this can be concluded that In-vitro produced plants has more capacity to accumulate or uptake heavy metal as compared to In-vivo produced plants. It means the phytochemical or the proteins which are responsible for metal up take produced more in Invitro produced plants.

\section{CONCLUSION:}

Impatiens balsamina L. has phytoremediation capacity and its hyperaccumulator plant for specific lead and cadmium metals. For on site pollution deduction from the soil In-vitro plantlets can be used because they can accumulate or uptake or extract more amount of heavy metal from the soil. So, it's one application that can be added of tissue cultured plant. After the treatment the plant material which is obtained that can be utilised for the production of "Biochar" which can be used as fuel in different industries and specially used as secondary component for the preparation of Tier and Tube Industry.

\section{REFERENCES:}

Cano-Ruiz, J., Galea, M. R., Amorós, M. C., Alonso, J., Mauri, P. V., \& Lobo, M. C. (2020). Assessing Arundo donax L. in vitro-tolerance for phytoremediation purposes. Chemosphere, 126576

Chaney, R. L., Malik, M., Li, Y. M., Brown, S. L., Brewer, E. P., Angle, J. S., \& Baker, A. J. (1997). Phytoremediation of soil metals. Current opinion in Biotechnology, 8(3), 279-284.

Di Lonardo, S., Capuana, M., Arnetoli, M., Gabbrielli, R., \& Gonnelli, C. (2011). Exploring the metal phytoremediation potential of three Populus alba L. clones using an in vitro screening. Environmental Science and Pollution Research, 18(1), 82-90.

Doty, S. L. (2008). Enhancing phytoremediation through the use of transgenics and endophytes. New Phytologist, 179(2), 318-333.

Elloumi, N., Belhaj, D., Mseddi, S., Zouari, M., Abdallah, F. B., Woodward, S., \& Kallel, M. (2017). Response of Nerium oleander to phosphogypsum amendment and its potential use for phytoremediation. Ecological Engineering, 99, 164-171.

Ikeura, H., Kawasaki, Y., Kaimi, E., Nishiwaki, J., Noborio, K., \& Tamaki, M. (2016). Screening of plants for phytoremediation of oilcontaminated soil. International journal of phytoremediation, 18(5), 460-466.

Lone, M. I., He, Z. L., Stoffella, P. J., \& Yang, X. E. (2008). Phytoremediation of heavy metal polluted soils and water: progresses and perspectives. Journal of Zhejiang University Science B, 9(3), 210-220.

Mackova, M., Dowling, D., \& Macek, T. (Eds.). (2006). Phytoremediation and rhizoremediation (Vol. 9). Springer Science \& Business Media.

Raskin, I., \& Ensley, B. D. (2000). Phytoremediation of toxic metals. John Wiley and Sons.

Salt, D. E., Smith, R. D., \& Raskin, I. (1998). Phytoremediation. Annual review of plant biology, 49(1), 643-668. 
e-ISSN $2347-517 X$

Original Article
Satashiya, K. F. (2017). Phytoremediation Potential of Flowering Plants for $\mathrm{Cd}, \mathrm{Ni}$ and $\mathrm{Pb}$ Contaminated Soils (Doctoral dissertation, SOIL SCIENCE AND AGRICULTURAL CHEMISTRY, NM COLLEGE OF AGRICULTURE， NAVSARI AGRICULTURAL UNIVERSITY, NAVSARI).

Schnabel, W. E., \& White, D. M. (2001). The effect of mycorrhizal fungi on the fate of aldrin: phytoremediation potential. International Journal of Phytoremediation, 3(2), 221-241.

Sekar, K., Gunasekaran, D., \& Perumal, P. (2013). Phytoremediation of heavy metals in Golden
Doranda, Balsam and Eerwa plants. Journal of Chemical and Pharmaceutical Research, 5(12), 1500-1511.

Suresh, B., \& Ravishankar, G. A. (2004). Phytoremediation-a novel and promising approach for environmental clean-up. Critical reviews in biotechnology, 24(2-3), 97-124.

Tangahu, B. V., Sheikh Abdullah, S. R., Basri, H., Idris, M., Anuar, N., \& Mukhlisin, M. (2011). A review on heavy metals $(\mathrm{As}, \mathrm{Pb}$, and $\mathrm{Hg}$ ) uptake by

$$
\text { plants }
$$

through phytoremediation. International Journal of Chemical Engineering, 2011. 


\section{LIST OF TABLES:}

Table:1 Showing the Composition and Components of M. S. Media (1962) preparation

\begin{tabular}{|c|c|c|c|c|}
\hline \multirow[t]{2}{*}{ Stock } & \multirow[t]{2}{*}{ Constituents } & \multicolumn{2}{|c|}{ Quantity } & \multirow[t]{2}{*}{ Stock medium } \\
\hline & & 1 liter (gm) & 10 liter (gm) & \\
\hline \multirow[t]{6}{*}{ A. } & Major Stock (gm) & & & \\
\hline & Ammonium Nitrate $\left(\mathrm{NH}_{4} \mathrm{NO}_{3}\right)$ & 1.65 & 16.5 & \\
\hline & Potassium Nitrate $\left(\mathrm{KNO}_{3}\right)$ & 1.9 & 19 & $500 \mathrm{ml}$ \\
\hline & Calcium Chloride $\left(\mathrm{CaCl}_{2} .2 \mathrm{H}_{2} \mathrm{O}\right)$ & 0.44 & 4.4 & \\
\hline & $\begin{array}{l}\text { Magnesium Sulphate } \\
\left(\mathrm{MgSO}_{4} .7 \mathrm{H}_{2} \mathrm{O}\right)\end{array}$ & 0.37 & 3.7 & \\
\hline & Monobasic Potassium $\left(\mathrm{KH}_{2} \mathrm{PO}_{4}\right)$ & 0.17 & 1.7 & \\
\hline \multirow[t]{8}{*}{ B. } & Minor Stock (mg) & (mg) & (mg) & \\
\hline & Potassium Iodide (KI) & 0.83 & 8.3 & \\
\hline & Boric Acid $\left(\mathrm{H}_{3} \mathrm{BO}_{3}\right)$ & 6.2 & 62 & \\
\hline & $\begin{array}{l}\text { Manganese Sulphate } \\
\left(\mathrm{MnSO}_{4} .4 \mathrm{H}_{2} \mathrm{O}\right)\end{array}$ & 22.3 & 223 & \\
\hline & Cobalt Chloride $\left(\mathrm{CoCl}_{2} \cdot 6 \mathrm{H}_{2} \mathrm{O}\right)$ & 0.025 & 0.25 & $500 \mathrm{ml}$ \\
\hline & Zinc Sulphate $\left(\mathrm{ZnSO}_{4} .7 \mathrm{H}_{2} \mathrm{O}\right)$ & 8.6 & 86 & \\
\hline & $\begin{array}{l}\text { Sodium Molybdate } \\
\left(\mathrm{Na}_{2} \mathrm{MoO}_{4} .2 \mathrm{H}_{2} \mathrm{O}\right)\end{array}$ & 0.25 & 2.5 & \\
\hline & Copper Sulphate $\left(\mathrm{CuSO}_{4} .5 \mathrm{H}_{2} \mathrm{O}\right)$ & 0.025 & 0.25 & \\
\hline \multirow[t]{3}{*}{ C. } & Iron Stock & $\overline{(\mathrm{mg})}$ & $\overline{(\mathrm{mg})}$ & \\
\hline & $\begin{array}{l}\text { Sodium EDTA } \\
\left(\mathrm{Na}_{2} \text { EDTA. } 2 \mathrm{H}_{2} \mathrm{O}\right)\end{array}$ & 37.3 & 373 & $500 \mathrm{ml}$ \\
\hline & Ferric Sulphate $\left(\mathrm{FeSO}_{4} .7 \mathrm{H}_{2} \mathrm{O}\right)$ & 27.8 & 278 & \\
\hline \multirow[t]{4}{*}{ D. } & Vitamin Stock & $(\mathrm{mg})$ & $(\mathrm{mg})$ & \\
\hline & Nicotinic Acid & 0.5 & 5 & \\
\hline & Pyridoxine $\mathrm{HCl}$ & 0.5 & 5 & $100 \mathrm{ml}$ \\
\hline & Thymine $\mathrm{HCl}$ & 0.1 & 1 & \\
\hline E. & Myo Inositol & $100 \mathrm{mg}$ & \multirow{4}{*}{\multicolumn{2}{|c|}{$\begin{array}{l}\text { After the combination of all the required } \\
\text { stocks for } 1 \text { litter all these weighed } \\
\text { chemicals were added in that combination } \\
\text { of solution for the preparation of media. }\end{array}$}} \\
\hline F. & Glyine & $2 \mathrm{mg}$ & & \\
\hline G. & Agar-Agar & $8 \mathrm{mg}$ & & \\
\hline H. & Sucrose & $30 \mathrm{gm}$ & & \\
\hline
\end{tabular}


Table:2 Results table showing accumulation of Lead in different parts of In-vitro produced plants.

\begin{tabular}{|c|c|c|c|}
\hline \multicolumn{4}{|c|}{ In-vitro produced Balsam } \\
\hline Treatment & $\mathrm{Pb}$ in roots $\mathrm{mg} / \mathrm{kg}$ & $\mathrm{Pb}$ in Stem $\mathrm{mg} / \mathrm{kg}$ & $\mathrm{Pb}$ in leaves $\mathrm{mg} / \mathrm{kg}$ \\
\hline Control & $11.23 \pm 1.15$ & $6.29 \pm 0.30$ & $2.42 \pm 0.22$ \\
\hline 400mg/kg & $1510 \pm 10.40$ & $909 \pm 6.42$ & $769 \pm 5.90$ \\
\hline $800 \mathrm{mg} / \mathrm{kg}$ & $1840 \pm 4.20$ & $1430 \pm 7.80$ & $905 \pm 4.20$ \\
\hline
\end{tabular}

Table:3 Result Table showing accumulation of Lead in different parts of In-vivo produced plants.

\begin{tabular}{|c|c|c|c|}
\hline \multicolumn{4}{|c|}{ In-vivo produced Balsam } \\
\hline Treatment & Pb in roots $\mathbf{~ m g / k g}$ & Pb in Stem $\mathbf{~ m g} / \mathbf{k g}$ & Pb in Leaves mg/ kg \\
\hline Control & $8.09 \pm 0.90$ & $4.2 \pm 0.25$ & $1.02 \pm 0.08$ \\
\hline $400 \mathrm{mg} / \mathrm{kg}$ & $1489 \pm 9.40$ & $858 \pm 8.09$ & $601 \pm 4.02$ \\
\hline $800 \mathrm{mg} / \mathrm{kg}$ & $1742 \pm 8.82$ & $1389 \pm 4.80$ & $915 \pm 2.41$ \\
\hline
\end{tabular}

Table:4 Results Table showing accumulation of Cadmium in different parts of In-vitro produced plants.

\begin{tabular}{|c|c|c|c|}
\hline \multicolumn{4}{|c|}{ In-vitro produced Balsam } \\
\hline Treatment & Cd in Roots mg/kg & Cd in Stem mg/kg & Cd in Leaves $\mathrm{mg} / \mathrm{kg}$ \\
\hline Control & $0.85 \pm 0.9$ & $0.58 \pm 0.09$ & $0.25 \pm 0.04$ \\
\hline $10 \mathrm{mg} / \mathrm{kg}$ & $80.60 \pm 6.20$ & $40.02 \pm 2.10$ & $25.40 \pm 1.32$ \\
\hline $20 \mathrm{mg} / \mathrm{kg}$ & $89.00 \pm 9.40$ & $54.00 \pm 3.90$ & $30 \pm 1.89$ \\
\hline
\end{tabular}

Table:5 Result Table showing accumulation of Cadmium in different parts of In-vivo produced plants.

\begin{tabular}{|c|c|c|c|}
\hline \multicolumn{4}{|c|}{ In-vivo produced Balsam } \\
\hline Treatment & Cd in Roots $\mathrm{mg} / \mathrm{kg}$ & Cd in Stem $\mathrm{mg} / \mathrm{kg}$ & Cd in Leaves $\mathrm{mg} / \mathrm{kg}$ \\
\hline Control & $0.79 \pm 0.05$ & $0.49 \pm 0.09$ & $0.16 \pm 0.03$ \\
\hline $10 \mathrm{mg} / \mathrm{kg}$ & $78.40 \pm 5.90$ & $33.00 \pm 4.02$ & $18.02 \pm 1.37$ \\
\hline $20 \mathrm{mg} / \mathrm{kg}$ & $70.02 \pm 6.04$ & $39.0 \pm 4.40$ & $19.0 \pm 2.21$ \\
\hline
\end{tabular}





\section{LIST OF FIGURES:}

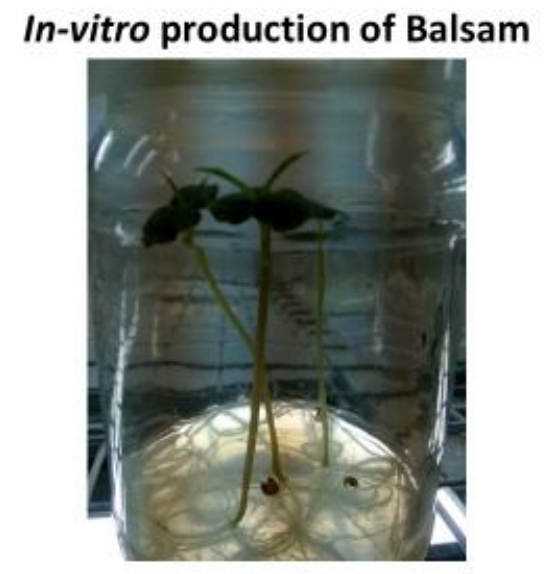

In-vivo production of Balsam

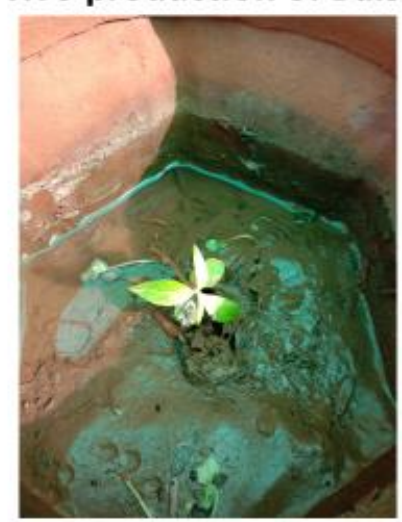


Preparation of Mature plants for Transplantation



\section{Treatment of heavy metals to the} plants

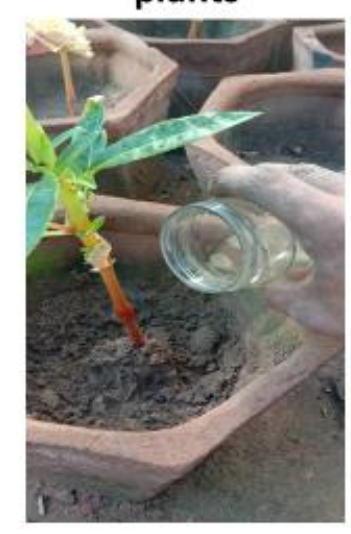

Transplanted all the plantlets in pots with $5 \mathrm{~kg}$ of soil

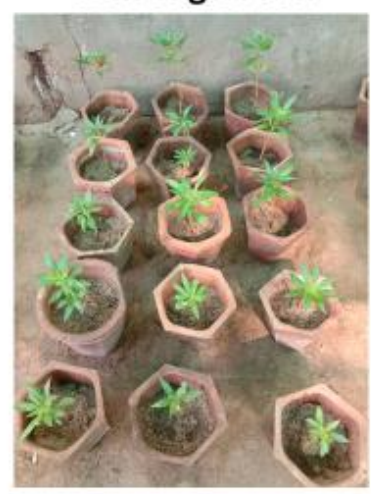

\section{After Incubation Collection of plants}

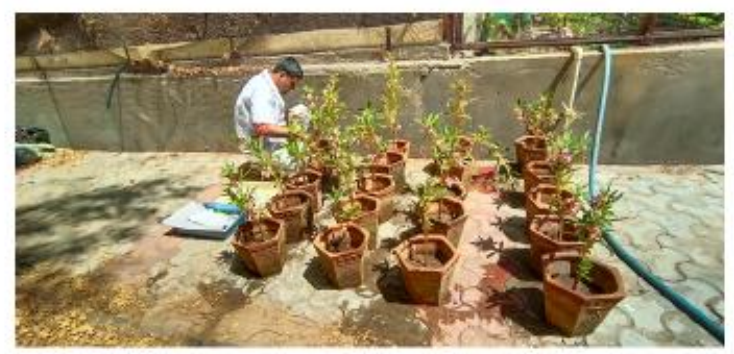

Collected Treated plants with control series

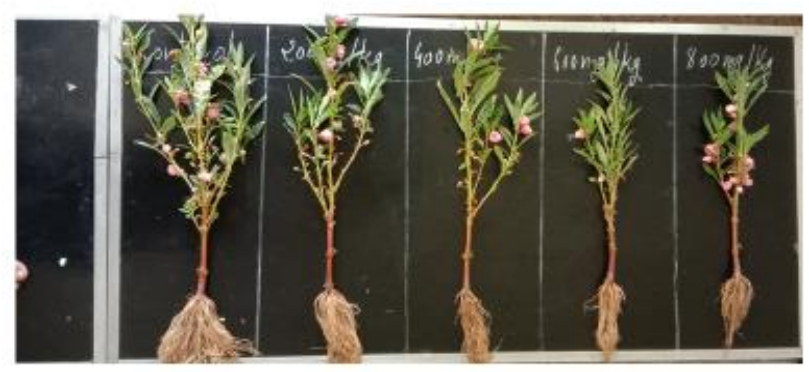

Separation of all the parts of the plants as per different Concentrations






\section{Acid digestion $\mathbf{1}^{\text {st }}$ step (concentrated} Nitric Acid)

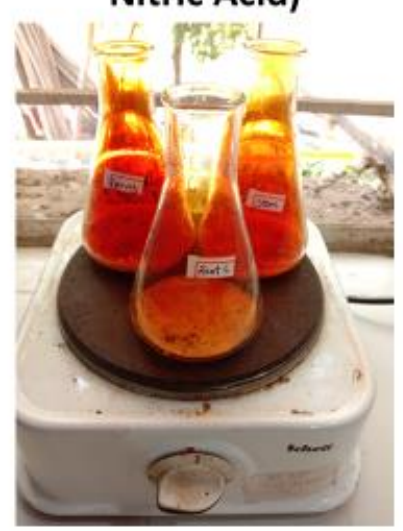

Acid Digestion $3^{\text {rd }}$ Step (Distilled water)

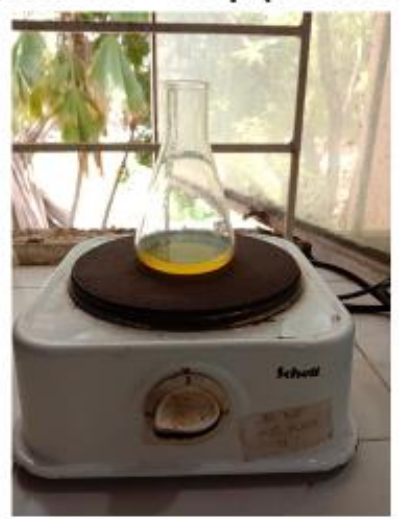

Acid digestion $2^{\text {nd }}$ step $(70 \%$ Perchloric Acid)



Filtration after cooling (Filter paper-44)

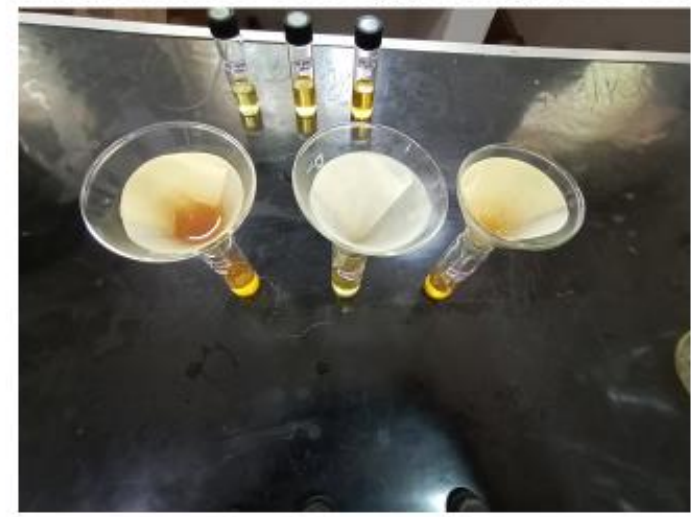

